\title{
22. PHYTOLITHS FROM THE SOUTHWEST PACIFIC, SITE 591
}

\author{
Sigurd Locker and Erlend Martini, Geologisch-Paläontologisches Institut der Universität, Frankfurt am Main ${ }^{2}$
}

\begin{abstract}
Phytoliths are described from deep sea sediments at Site 591 in the southwestern Pacific. Their regional distribution is related to the arid and semiarid regions of Australia, from where they were blown by westerly winds into the Tasman Sea area. The stratigraphic record ranges from the middle Miocene, at about 14.4 m.y., until the early Pleistocene. A distinct increase in frequencies observed during the Pliocene and a maximum at about 2.5 m.y. coincide with important trends in paleogeography and paleoclimatology: the development of the Antarctic ice cap, the northward drift of the Australian Plate, and the generation of arid conditions on the Australian continent.
\end{abstract}

\section{INTRODUCTION}

During Leg 90 phytoliths were found in fair numbers in Holes 591, 591A, and 591B, and very sporadically also in Hole 594A. They were investigated in detail only in the first three holes. Site 591 is situated on the eastern flank of the Lord Howe Rise $\left(31^{\circ} 35.06^{\prime} \mathrm{S} ; 164^{\circ} 26.92^{\prime} \mathrm{E}\right)$ in a present water depth of $2131 \mathrm{~m}$ (Fig. 1). Sediments recovered at this site consist mainly of foraminifer-bearing or foraminifer-rich nannofossil ooze. Biosiliceous components are present in low numbers compared with calcareous components, and include diatoms, silicoflagellates, radiolarians, and phytoliths. The investigated sections cover the middle Miocene to early Pleistocene interval.

\section{PHYTOLITHS IN MARINE SEDIMENTS}

Phytoliths are siliceous casts of various shapes that occur mainly in epidermal cells of grasses. They generally indicate that a certain fraction of a sediment sample is derived from a terrestial source.

Phytoliths have been described from terrestial localities (Ehrenberg, 1854; Baker, 1960a; Deflandre, 1963; Hajós, 1968) as well as from marine sections (see Table 1). In marine sediments they commonly occur in areas which are close to continents and where permanent eolian transport of dust in particular directions is possible (Folger et al., 1967; Folger, 1970). The main areas of phytolith distribution are in the Atlantic Ocean off the coast of northwest Africa and in the eastern equatorial Pacific. In both areas easterly winds, that is, winds blowing in a westerly direction, cause phytoliths to occur in Recent and ancient sediments. To these occurrences we can now add the southwest Pacific, where phytoliths were found in fair numbers during Leg 90 of the Deep Sea Drilling Project, distributed from Australia by westerly winds.

\footnotetext{
${ }^{1}$ Kennett, J. P., von der Borch, C. C., et al., Init. Repts. DSDP, 90: Washington (U.S. Govt, Printing Office).

2 Addresses: (Locker, present address) Geologisch-Paläontologisches Institut der Universität, Olshausenstrasse 40/60, D-2300 Kiel, Federal Republic of Germany; (Martini) Geologischsität, Olshausenstrasse 40/60, D-2300 Kiel, Federal Republic of Germany; (Martini) Geologisch-
Paläontologisches Institut der Universität, Senckenberg-Anlage 32-34, D-6000 Frankfurt am Main, Federal Republic of Germany.
}

The stratigraphic occurrence of phytoliths in marine sediments is presently known to cover the middle Eocene to the Quaternary, with a distinct increase in frequencies in several sections of the Pliocene and Pleistocene (Table 1).

\section{PHYTOLITH CLASSIFICATION}

Phytoliths are composed of opaline silica. Their appearance under the microscope is colorless in normal light but may also tend to grey or brown. Size is commonly below $30 \mu \mathrm{m}$ but can reach $60 \mu \mathrm{m}$ and more. Their shape varies from simple, rounded, or angular bodies to dumbbell-shaped or rodlike bodies.

Two systematic concepts are in use to describe the variety found in phytoliths, but neither is very satisfactory. One concept uses only a descriptive nomenclature (Twiss et al., 1969; Bukry, 1980), and the other one a fixed nomenclature with parataxa (Deflandre, 1963; Dumitricà 1973), because phytoliths of identical shape may occur in grasses of quite different taxonomic positions.

In the present study we prefer the concept of Deflandre (1963), which is based on Ehrenberg (1854), and includes the three genera Lithodontium, Lithomesites, and Lithostylidium. However, we treat these genera in the following sense: (1) lithodontioid group = phytoliths commonly conical or tetragonal, but also polygonal in outline; (2) lithomesitoid group = dumbbell-shaped phytoliths composed of two globules connected by a neck; (3) lithostyloid group = rodlike phytoliths showing a smooth, undulate, serrate, or spiny margin.

\section{SITE 591 SUMMARY}

The section for the present phytolith study is combined from the following intervals: Hole 591A-3,CC to 591A-10,CC for the upper part (upper Pliocene and Pleistocene); Hole 591-11,CC to 591-31,CC for the middle part (upper Miocene to lower upper Pliocene); and Hole 591B-2,CC to 591B-24,CC for the lower part (middle Miocene to lower upper Miocene). Only core-catcher samples were investigated, and as a result no phytolith data are available for calcareous nannoplankton Zones NN13 and NN17 in Table 2.

As shown in Table 2 and Figure 2, phytoliths commonly occur in low numbers in the middle and upper 


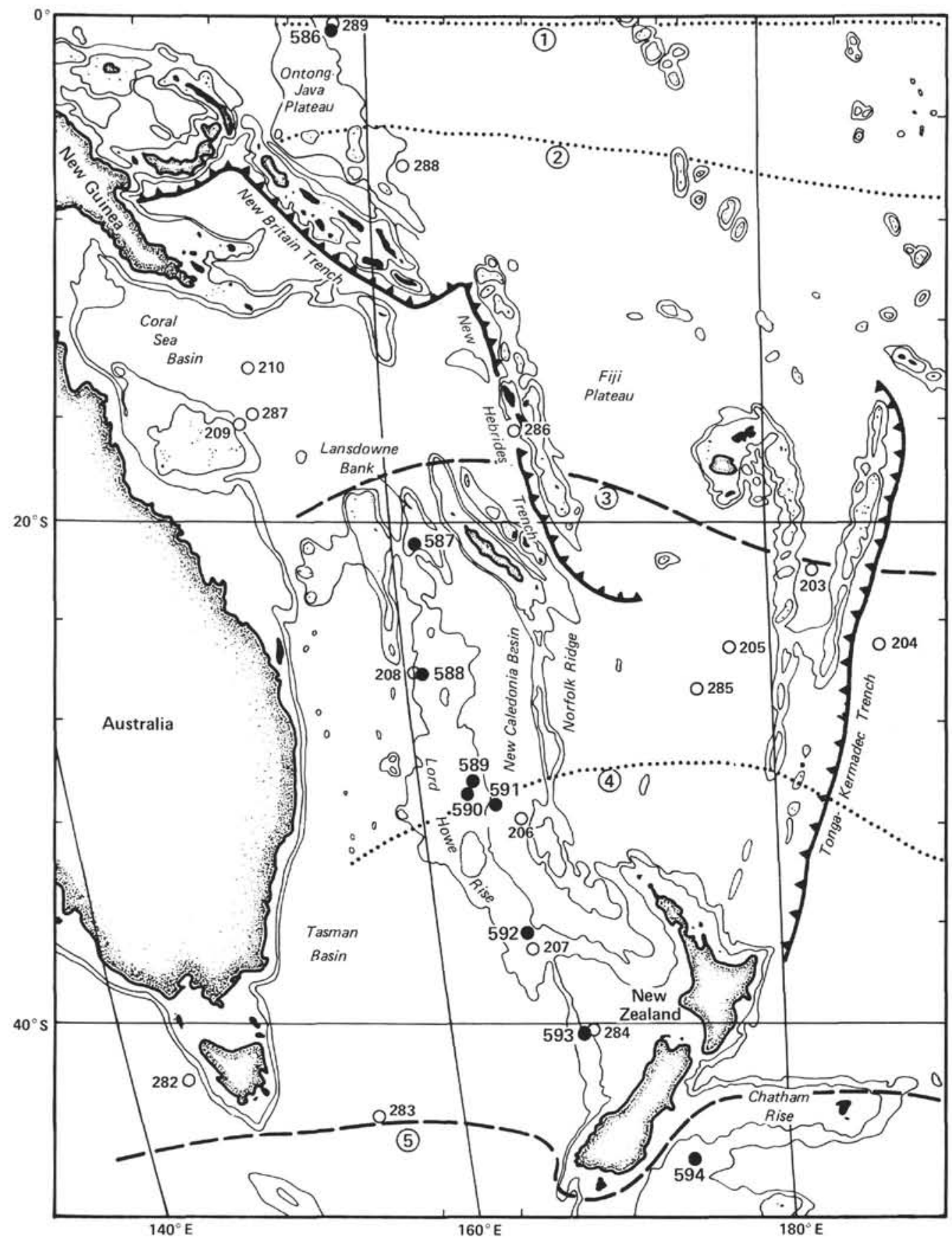

Figure 1. Locations of sites drilled during Leg 90 (solid circles) and other DSDP drill sites (open circles) in the southwest Pacific. Phytoliths are described only from Site 591.

Miocene part of the section, and some levels are barren, especially in the lowest part, comparable with nannoplankton zones NN4 and NN5 (Samples 591B-17,CC to 591B-24,CC). A rather sudden increase in frequencies can be noted with the early Pliocene: lithodontioid, lithomesitoid, and lithostyloid phytoliths are rather common in the upper lower Pliocene and upper Pliocene. Around the Pliocene/Pleistocene boundary two samples (591A$5, \mathrm{CC}$ and 591A-6,CC) are barren of phytoliths, but they reappear in Pleistocene Samples 591A-3,CC and 591A4,CC.

\section{PALEOCLIMATOLOGICAL INTERPRETATION}

Judging by frequencies of occurrence and assumed transport mechanisms, the phytoliths are considered to be derived mainly from the Australian continent. As proved by palynological studies, large, open grasslands developed during the late Neogene in the northern and central regions of Australia (Kemp, 1978), supplying the phytoliths found at Site 591. By analogy with recent conditions (Baker, 1960b; Healy, 1970; Ramage, 1970; Thiede, 1979), strong westerly winds must have blown phyto- 
Table 1. Known distribution of phytoliths in marine sediments.

\begin{tabular}{|c|c|c|c|}
\hline Author & Locality & $\begin{array}{l}\text { Time } \\
\text { interval }\end{array}$ & $\begin{array}{l}\text { Geographic } \\
\text { source }\end{array}$ \\
\hline \multicolumn{4}{|c|}{ Atlantic Ocean and Mediterranean Sea } \\
\hline Kolbe, 1955, 1957 & $\begin{array}{l}\text { N Atlantic, off NW } \\
\text { Africa }\end{array}$ & Quaternary & Africa \\
\hline Dumitrică, 1973 & $\begin{array}{l}\text { Mediterranean Sea } \\
\text { (DSDP Sites 124, 130, } \\
\text { 131) }\end{array}$ & $\begin{array}{l}\text { Miocene (Site 124), Quater- } \\
\text { nary (Sites 130, 131) }\end{array}$ & Mediterranean Region \\
\hline Hajós, 1973 & $\begin{array}{l}\text { Mediterranean Sea } \\
\quad \text { (DSDP Sites 124, 130) }\end{array}$ & $\begin{array}{l}\text { Miocene (Site 124), Quater- } \\
\text { nary (Site 130) }\end{array}$ & Mediterranean Region \\
\hline Schrader, $1978 b$ & $\begin{array}{l}\text { SE Atlantic, Walvis Ridge } \\
\text { (DSDP Site 362) }\end{array}$ & Miocene, Pliocene, Quaternary & Africa \\
\hline \multirow[t]{2}{*}{ Schrader, 1978a } & $\begin{array}{l}\text { N Atlantic, off NW } \\
\text { Africa (DSDP Site } \\
\text { 369) }\end{array}$ & Eocene, Oligocene, Miocene & Africa \\
\hline & $\begin{array}{l}\text { Equatorial E Atlantic, } \\
\text { Sierra Leone Rise } \\
\text { (DSDP Site 366) }\end{array}$ & $\begin{array}{l}\text { Oligocene, Miocene, Quater- } \\
\text { nary }\end{array}$ & \\
\hline Bukry, 1979b & $\begin{array}{l}\text { N Atlantic, off NW } \\
\text { Africa (DSDP Site } \\
\text { 397) }\end{array}$ & Pliocene, Quaternary & Africa \\
\hline \multirow[t]{2}{*}{ Bukry, 1979a } & $\begin{array}{l}\text { N Atlantic, Mid-Atlantic } \\
\text { Ridge (DSDP Sites } \\
410,412 \text { ) }\end{array}$ & Pliocene/Quaternary & Africa? \\
\hline & $\begin{array}{l}\text { Off SW Iceland (DSDP } \\
\text { Site 408) }\end{array}$ & Pliocene & Iceland? \\
\hline \multicolumn{4}{|c|}{ Pacific Ocean } \\
\hline \multirow[t]{2}{*}{ Bukry, 1980} & $\begin{array}{l}\text { Equatorial E Pacific } \\
\text { (DSDP Site 425) }\end{array}$ & Quaternary & $\begin{array}{l}\text { Mexico and Central } \\
\text { America }\end{array}$ \\
\hline & $\begin{array}{l}\text { East Pacific Rise (DSDP } \\
\text { Sites } 419,420,422, \\
427,428)\end{array}$ & Pliocene, Quaternary & \\
\hline $\begin{array}{l}\text { Locker and Martini, } \\
\text { this paper }\end{array}$ & $\begin{array}{l}\text { SW Pacific (DSDP Sites } \\
591,594)\end{array}$ & Miocene, Pliocene, Quaternary & Australia \\
\hline
\end{tabular}

lith-bearing dusts from the arid and semiarid regions of Australia into the investigated area, which is situated more than $1000 \mathrm{~km}$ off the coast. We can deduce from recent conditions that the phytoliths were probably swept from the ground by gusts during cyclonal activity, and lifted up into higher layers of the troposphere. There, in the zone of upper westerly winds, they may have been transported over long distances, especially if enclosed in the subtropical jetstream (recent data in Healy, 1970, and Lamb, 1972).

As shown in Figure 2, phytoliths were first found at about 14.4 m.y., comparable to nannoplankton Zone NN6, middle Miocene. This record provides a more precise date for the initial phase of open grassland formation in Australia than hitherto determined from palynological studies (Kemp, 1978). Generally, the middle Miocene appearance of phytoliths seems to reflect the complex co-operation of various geographical and climatological factors such as:

1. The permanent northward drift of the Indo-Australian Plate after its separation from Antarctica, and its successive penetration into the mid-latitudes (Edwards, 1975; Kemp, 1978), that is, to zones of increased solar radiation (recent data in Lamb, 1972).

2. The development of a large Antarctic ice mass associated with steeper temperature gradients between high and low southern latitudes (Hayes and Frakes, 1975; Kennett, Houtz, et al., 1975; Shackleton and Kennett, 1975; Kennett, 1977; Keigwin, 1979) and the intensification of the wind system (Hayes and Frakes, 1975; Kemp, 1978). Accompanying these processes, came:

3. The initiation of arid conditions in the northern and northwestern parts of Australia, followed by the development of open grasslands (Kemp, 1978). From their first appearance up to the uppermost Miocene, phytoliths are distributed in relatively low frequency. But starting with nannoplankton Zone NN12, at about $5.1 \mathrm{~m} . \mathrm{y}$. (early Pliocene), they suddenly occur in higher numbers. After that, phytolith quantities are drastically increased towards the late Pliocene, showing a maximum in nannoplankton Zone NN16, at about 2.5 m.y.

This evolution may be related to developments in the trends described above. It has been demonstrated that:

1. The Antarctic ice sheet attained its maximum dimensions in the latest Miocene to earliest Pliocene (Hayes and Frakes, 1975; Kennett, Houtz, et al., 1975; Kennett, 1977; Mercer and Sutter, 1982; Ciesielski and Weaver, 1983). This was surely accompanied by stronger winds in mid and low latitudes (Hayes and Frakes, 1975; Stein, 1984).

2. The Australian Plate shifted to nearly its recent position in the late Miocene (Edwards, 1975; Kemp, 1978). This must have effected the aridification of vast areas.

The coincidence of both processes obviously led to an expansion of open grasslands in Australia, to the production of large quantities of phytoliths, and to an intensified transport of dust into the eastern seas. It is noteworthy that phytolith frequency does not increase in 
Table 2. Distribution of phytoliths in selected samples from Holes 591, 591A, and 591B, and correlation to standard nannoplankton zones.

\begin{tabular}{|c|c|c|c|c|c|c|c|}
\hline Age & $\begin{array}{l}\text { Nannoplankton } \\
\text { zones }\end{array}$ & Samples & 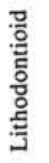 & 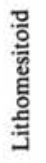 & 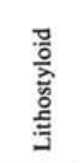 & 苛 & $\begin{array}{l}\text { हूँ } \\
\text { 苂 } \\
\text { के }\end{array}$ \\
\hline Quaternary & NN19 & $\begin{array}{r}591 \mathrm{~A} 3, \mathrm{CC} \\
4, \mathrm{CC} \\
5, \mathrm{CC}\end{array}$ & $\begin{array}{l}4 \\
4\end{array}$ & $\begin{array}{l}3 \\
4\end{array}$ & $\begin{array}{c}2 \\
4 \\
\text { Barren }\end{array}$ & 1 & $\begin{array}{r}31 \\
102\end{array}$ \\
\hline \multirow[b]{2}{*}{$\begin{array}{l}\text { upper } \\
\text { Pliocene }\end{array}$} & NN18 & \multirow{2}{*}{$\begin{array}{r}6, \mathrm{CC} \\
7, \mathrm{CC} \\
8, \mathrm{CC} \\
9, \mathrm{CC} \\
10, \mathrm{CC} \\
59111, \mathrm{CC}\end{array}$} & \multirow[b]{2}{*}{$\begin{array}{l}4 \\
5 \\
4 \\
5 \\
4\end{array}$} & \multicolumn{3}{|c|}{ Barren } & \\
\hline & NN16 & & & $\begin{array}{l}4 \\
4 \\
4 \\
4\end{array}$ & $\begin{array}{l}4 \\
3 \\
4 \\
3\end{array}$ & 1 & $\begin{array}{r}113 \\
65 \\
96 \\
75\end{array}$ \\
\hline \multirow{3}{*}{$\begin{array}{l}\text { lower } \\
\text { Pliocene }\end{array}$} & NN15 & \multirow{3}{*}{$\begin{array}{l}13, \mathrm{CC} \\
14, \mathrm{CC} \\
16, \mathrm{CC} \\
17, \mathrm{CC} \\
18, \mathrm{CC} \\
19, \mathrm{CC} \\
20, \mathrm{CC} \\
21, \mathrm{CC} \\
22, \mathrm{CC} \\
23, \mathrm{CC}\end{array}$} & \multirow{3}{*}{$\begin{array}{l}4 \\
4 \\
4 \\
4 \\
4 \\
3 \\
4 \\
3 \\
3 \\
3 \\
3 \\
3\end{array}$} & \multirow{3}{*}{\multicolumn{2}{|c|}{$\begin{array}{ll}4 & 4 \\
4 & 4 \\
4 & 3 \\
4 & 2 \\
3 & 2 \\
4 & 2 \\
3 & 3 \\
3 & 2 \\
3 & 2 \\
3 & 2\end{array}$}} & \multirow{3}{*}{$\begin{array}{l}2 \\
3 \\
2 \\
1 \\
2 \\
1 \\
1\end{array}$} & $\begin{array}{l}87 \\
84\end{array}$ \\
\hline & NN14 & & & & & & $\begin{array}{l}52 \\
22 \\
51\end{array}$ \\
\hline & NN12 & & & & & & $\begin{array}{l}24 \\
18 \\
18\end{array}$ \\
\hline \multirow{4}{*}{$\begin{array}{l}\text { upper } \\
\text { Miocene }\end{array}$} & NN11B & $\begin{array}{l}24, \mathrm{CC} \\
25, \mathrm{CC} \\
26, \mathrm{CC} \\
27, \mathrm{CC}\end{array}$ & $\begin{array}{l}2 \\
2 \\
2 \\
3\end{array}$ & $\begin{array}{l}2 \\
2 \\
2 \\
2\end{array}$ & $\begin{array}{l}2 \\
2 \\
1 \\
2\end{array}$ & \multirow{4}{*}{1} & $\begin{array}{r}10 \\
10 \\
9 \\
12\end{array}$ \\
\hline & NN11A & $\begin{array}{r}28, \mathrm{CC} \\
29, \mathrm{CC} \\
30, \mathrm{CC} \\
591 \mathrm{~B} 2, \mathrm{CC} \\
3, \mathrm{CC} \\
4, \mathrm{CC}\end{array}$ & $\begin{array}{l}2 \\
1 \\
2 \\
1 \\
1\end{array}$ & $\begin{array}{l}2 \\
2 \\
3 \\
3 \\
1 \\
2\end{array}$ & $\begin{array}{l}1 \\
2 \\
1 \\
1 \\
2 \\
2\end{array}$ & & $\begin{array}{r}3 \\
10 \\
8 \\
13 \\
6 \\
6 \\
8\end{array}$ \\
\hline & NN10 & $\begin{array}{l}5, \mathrm{CC} \\
6, \mathrm{CC} \\
7, \mathrm{CC}\end{array}$ & $\begin{array}{l}2 \\
2\end{array}$ & $\begin{array}{l}2 \\
2\end{array}$ & $\begin{array}{c}2 \\
2 \\
\text { Barren }\end{array}$ & & $\begin{array}{r}11 \\
6\end{array}$ \\
\hline & NN9 & $9, \mathrm{CC}$ & 2 & 1 & 1 & & 6 \\
\hline \multirow{3}{*}{$\begin{array}{l}\text { middle } \\
\text { Miocene }\end{array}$} & $\begin{array}{l}\text { NN8 } \\
\text { NN7 }\end{array}$ & $\begin{array}{l}10, \mathrm{CC} \\
11, \mathrm{CC}\end{array}$ & $\begin{array}{l}2 \\
2\end{array}$ & $\begin{array}{l}2 \\
2\end{array}$ & & & $\begin{array}{l}8 \\
6 \\
3\end{array}$ \\
\hline & NN6 & $\begin{array}{l}13, \mathrm{CC} \\
14, \mathrm{CC}\end{array}$ & $\begin{array}{l}1 \\
1\end{array}$ & $\begin{array}{l}2 \\
2 \\
2\end{array}$ & 1 & & $\begin{array}{l}5 \\
6\end{array}$ \\
\hline & NN4/NN6 & $\begin{array}{l}16, \mathrm{CC} \\
17, \mathrm{CC} \\
\text { to } 24, \mathrm{CC}\end{array}$ & 1 & 1 & $\begin{array}{c}1 \\
\text { Barren }\end{array}$ & & \\
\hline
\end{tabular}

Note: Numbers indicate frequency of particular forms: $1=1$ specimen, $2=2$ to 5 specimens, $3=6$ to 15 specimens, $4=16$ to 50 specimens, $5=$ more than 50 specimens, counted in 4 rows $(=120 \mathrm{~mm})$ across the slides.

the late Miocene, with the assumed beginning of Antarctic ice expansion, but in the early Pliocene. Thus the rise apparently follows, after a slight delay, the prominent cooling event across the Miocene/Pliocene boundary that is evidenced by studies of oxygen isotopes (Shackleton and Kennett, 1975) and planktonic foraminifers in the Tasman Sea area (Kennett and Vella, 1975) and by investigations of ice rafting and the distribution of siliceous and calcareous sediments around Antarctica (Hayes and Frakes, 1975).

The distinct peak of phytolith frequency at about 2.5 m.y., late Pliocene, seems to be in response to the global decrease of temperature and the intensification of westerly winds which had been caused by the formation of the Northern Hemisphere ice sheet at about
3 m.y. (Berggren, 1972; Shackleton and Opdyke, 1977; Keigwin, 1979; Stein, 1984). But the processes causing the absence of phytoliths at the Pliocene/Pleistocene boundary remain unclear. On the one hand, the disappearance might be related to the glacial maximum around 2 m.y. (Shackleton and Opdyke, 1977; Keigwin, 1979; Stein, 1984), which might have changed common meteorological conditions, especially the winds. But on the other hand, selective dissolution of phytolith opal could also be responsible.

\section{ACKNOWLEDGMENTS}

Thanks are due to the Deutsche Forschungsgemeinschaft (BonnBad Godesberg) for supporting the present study. The Geologisch-Paläontologisches Institut der Universität Kiel provided space for laboratory work. Our thanks go also to J. Fenner, M. Sarnthein, and R. Stein (Kiel) for valuable discussions and to J. P. Kennett (University of Rhode Island) for comments and suggestions.

\section{REFERENCES}

Baker, G., 1960a. Fossil opal-phytoliths. Micropaleontology, 6:79-85. 1960b. Phytoliths in some Australian dusts. Proc. R. Soc. Victoria, 72:21-40.

Berggren, W. A., 1972. Late Pliocene-Pleistocene glaciation. In Laughton, A. S., Berggren, W. A., et al., Init. Repts. DSDP, 12: Washington (U.S. Govt. Printing Office), 953-963.

, 1979a. Coccolith and silicoflagellate stratigraphy, northern Mid-Atlantic Ridge and Reykjanes Ridge, Deep Sea Drilling Project Leg 49. In Luyendyk, B. P., Cann, J. R., et al., Init. Repts. DSDP,49: Washington (U.S. Govt. Printing Office), 551-581

Bukry, D., 1979b. Comments on opal phytoliths and stratigraphy of Neogene silicoflagellates and coccoliths at Deep Sea Drilling Project Site 397 off northwest Africa. In Luyendyk, B. P., Cann, J. R., et al., Init. Repts. DSDP, 49: Washington (U.S. Govt. Printing Office), 977-1009.

1980. Opal phytoliths from the tropical Pacific Ocean, Deep Sea Drilling Project Leg 54. In Rosendahl, B. R., Hekinian, R., et al., Init. Repts. DSDP, 54: Washington (U.S. Govt. Printing Office), 575-589.

Ciesielski, P. F., and Weaver, F. M., 1983. Neogene and Quaternary paleoenvironmental history of Deep Sea Drilling Project Leg 71 sediments, southwest Atlantic Ocean. In Ludwig, W. J., Krasheninnikov, V. A., et al., Init. Repts. DSDP, 71, Pt 1: Washington (U.S. Govt. Printing Office), 461-477.

Deflandre, G., 1963. Les Phytolithaires (Ehrenberg). Protoplasma, 57: 234-259.

Dumitricǎ, P., 1973. Phytolitharia. In Ryan, W. B. F., Hsü, K. J., et al., Init. Repts. DSDP, 13, Pt. 2: Washington (U.S. Govt. Printing Office), 940-943.

Edwards, A. R., 1975. Southwest Pacific Cenozoic paleogeography and an integrated Neogene paleocirculation model. In Andrews, J. E., Packham, G., et al., Init. Repts. DSDP, 30: Washington (U.S. Govt. Printing Office), 667-684.

Ehrenberg, C. G., 1854. Mikrogeologie. Das Erden und Felsen schaffende Wirken des unsichtbar kleinen selbststädigen Lebens auf der Erde: Leipzig (Leopold Voss).

Folger, D. W., 1970. Wind transport of land-derived mineral, biogenic, and industrial matter over the North Atlantic. Deep-Sea Res. 17:337-352.

Folger, D. W., Burckle, L. H., and Heezen, B. C., 1967. Opal phytoliths in North Atlantic dust fall. Science, 155:1243-1244.

Hajós, M., 1968. Magyarországi neogén Phytolithariák. Magyar All. Földt. Int., 1966, pp. 225-240.

1973. The Mediterranean diatoms. In Ryan, W. B. F., Hsü, K. J., et al., Init. Repts. DSDP, 13: Pt. 2: Washington (U.S. Govt. Printing Office), 944-969.

Hayes D. E., and Frakes, L. A., 1975. General synthesis, Deep Sea Drilling Project Leg 28. In Hayes, D. E., Frakes, L. A., et al., Init. Repts. DSDP, 28: Washington (U.S. Govt. Printing Office), 919-942.

Healy, T. R., 1970. Dust from Australia. Earth Sci. J., 4:106-116. 
Keigwin, L. D., 1979. Late Cenozoic stable isotope stratigraphy and paleoceanography of DSDP sites from the east equatorial and central north Pacific Ocean. Earth Planet Sci. Lett., 45:361-382.

Kemp, E. M., 1978. Tertiary climatic evolution and vegetation history in the Southeast Indian Ocean region. Palaeogeogr., Palaeoclimatol., Palaeoecol., 24:169-208.

Kennett, J. P., 1977. Cenozoic evolution of Antarctic glaciation, the Circum-Antarctic Ocean, and their impact on global paleoceanography. J. Geophys. Res., 82:3843-3860.

Kennett, J. P., Houtz, R. E., et al., 1975. Cenozoic paleoceanography in the southwest Pacific Ocean, Antarctic glaciation, and the development of the Circum-Antarctic Current. In Kennett, J. P., Houtz, R. E., et al., Init. Repts. DSDP, 29: Washington (U.S. Govt. Printing Office), 1155-1169.

Kennett, J. P., and Vella, P., 1975. Late Cenozoic planktonic foraminifera and paleoceanography at DSDP Site 284 in the cool subtropical South Pacific. In Kennett, J. P., Houtz, R. E., et al., Init. Repts. DSDP, 29: Washington (U.S. Govt. Printing Office), 769-799.

Kolbe, R. W., 1955. Diatoms from equatorial Atlantic cores. Rep. Swedish Deep-Sea Exp., 7:150-184.

1957. Fresh-water diatoms from Atlantic deep-sea sediments. Science, 126:1053-1056.

Lamb, H. H., 1972. Climate: Present, Past and Future (Vol. 1): Fundamentals and Climate Now: London (Methuen and Co.).

Mercer, J. H., and Sutter, J. F., 1982. Late Miocene-earliest Pliocene glaciation in southern Argentina: implications for global ice-sheet history. Palaeogeogr., Palaeoclimatol., Palaeoecol., 38:185-206.

Ramage, C. S., 1970. Meterology of the South Pacific tropical and middle latitudes. In Wooster, W. S. (Ed.), Scientific Exploration of the South Pacific: Washington (National Academy of Sciences), pp. 16-29.

1978a. Diatoms in DSDP Leg 41 Sites. In Lancelot, Y., Seibold, E., et al., Init. Repts. DSDP, 41: Washington (U.S. Govt. Printing Office), 791-812.

Schrader, H.-J., 1978b. Opal phytoplankton remains at DSDP Leg 40 Sites. In Bolli, H. M., Ryan, W. B. F., et al., Init. Repts. DSDP, Suppl. to Vols. 38, 39, 40, and 41: Washington (U.S. Govt. Printing Office), 735-741.

Shackleton, N. J., and Kennett, J. P., 1975. Paleotemperature history of the Cenozoic and the initiation of Antarctic glaciation: oxygen and carbon isotope analysis in DSDP Sites 277,279 , and 281 . In Kennett, J. P., Houtz, R. E., et al., Init. Repts. DSDP, 29: Washington (U.S. Govt. Printing Office), 743-755.

Shackleton, N. J., and Opdyke, N. D., 1977. Oxygen isotope and paleomagnetic evidence for early Northern Hemisphere glaciation. Nature, 270:216-219.

Stein, R., 1984. Zur neogenen Klimaentwicklung in Nordwest-Afrika und Paläo-Ozeanographie im Nordost-Atlantik: Ergebnisse von DSDP-Sites 141, 366, 397 und 544B. Ber. Geol. Paläont. Inst. Univ. Kiel, 4.

Thiede, J., 1979. Wind regimes over the late Quaternary southwest Pacific Ocean. Geology, 7:259-262.

Twiss, P. C., Suess, E., and Smith, R. M., 1969. Morphological classification of grass phytoliths. Proc. Soil Sci. Soc. Am., 33:109-115.

Date of Initial Receipt: 12 June 1984

Date of Acceptance: 26 October 1984

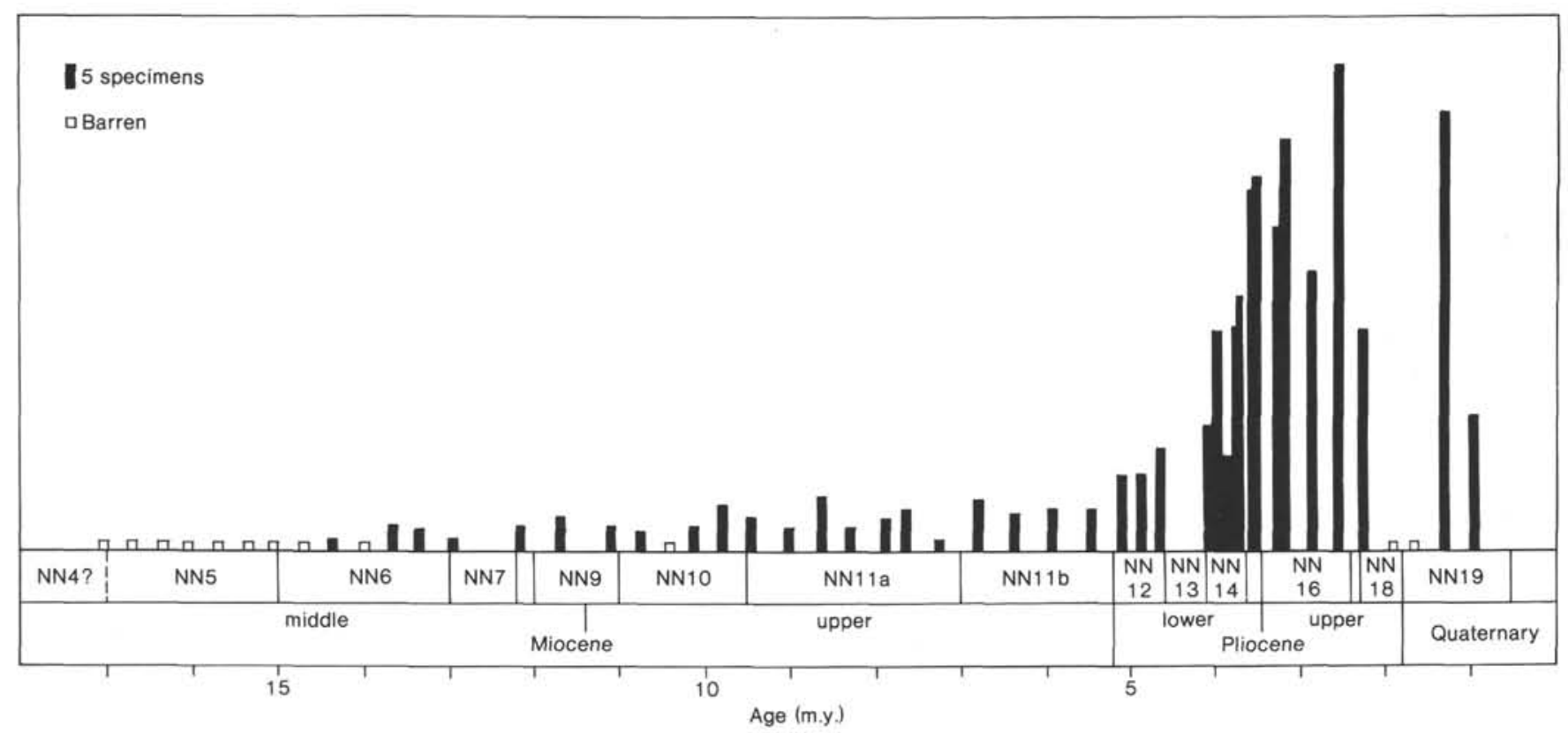

Figure 2. Frequency distribution of phytoliths found at Site 591, and correlation to standard nannoplankton zones. 

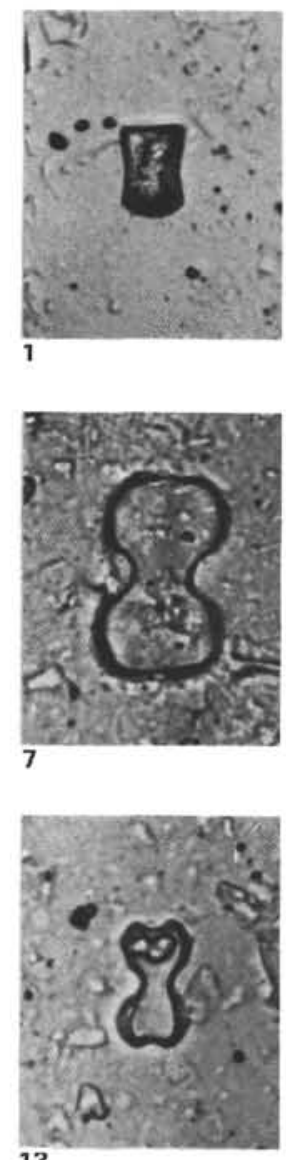

13

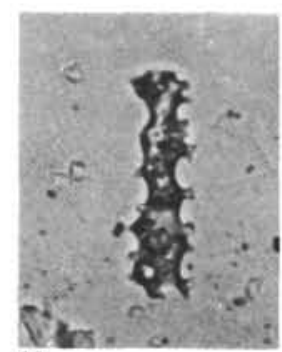

19

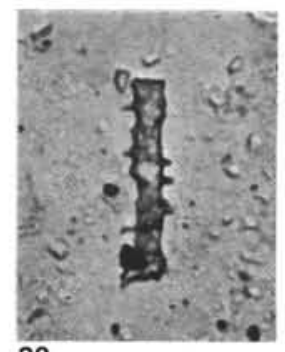

20

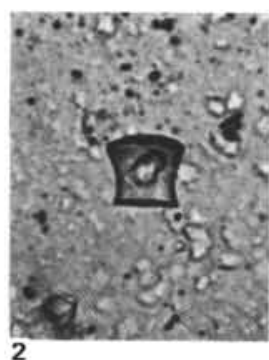

2
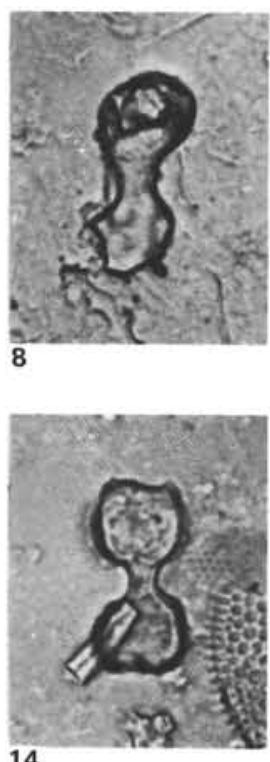

14

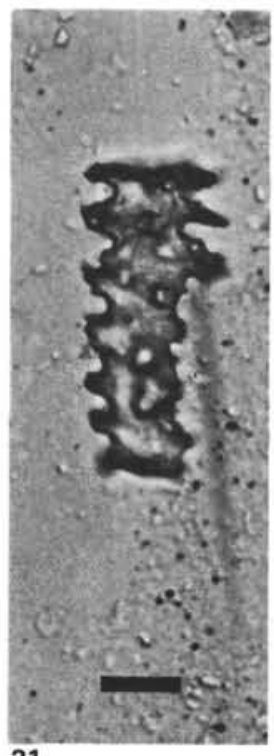

21

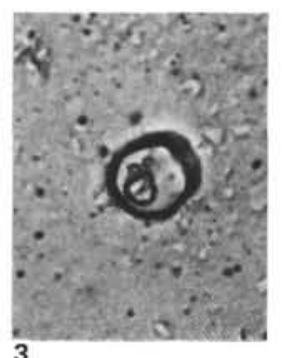

3

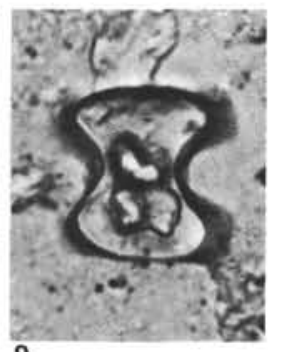

9

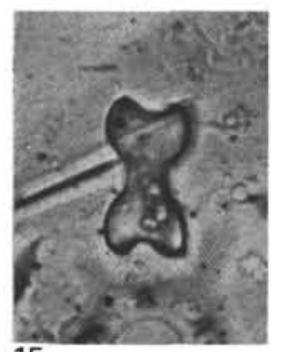

15

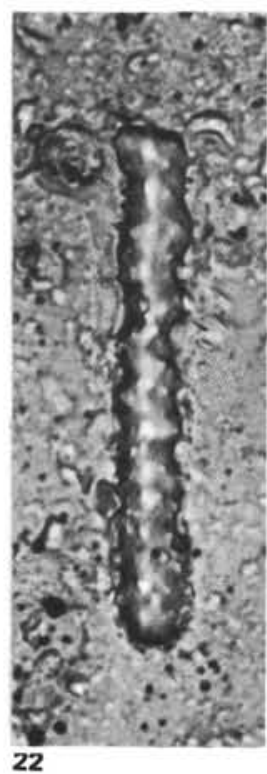

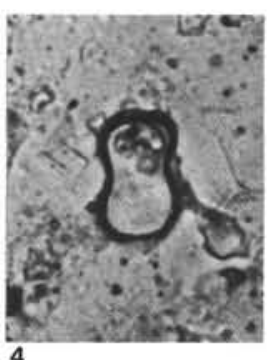

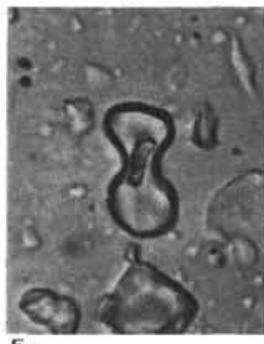

5
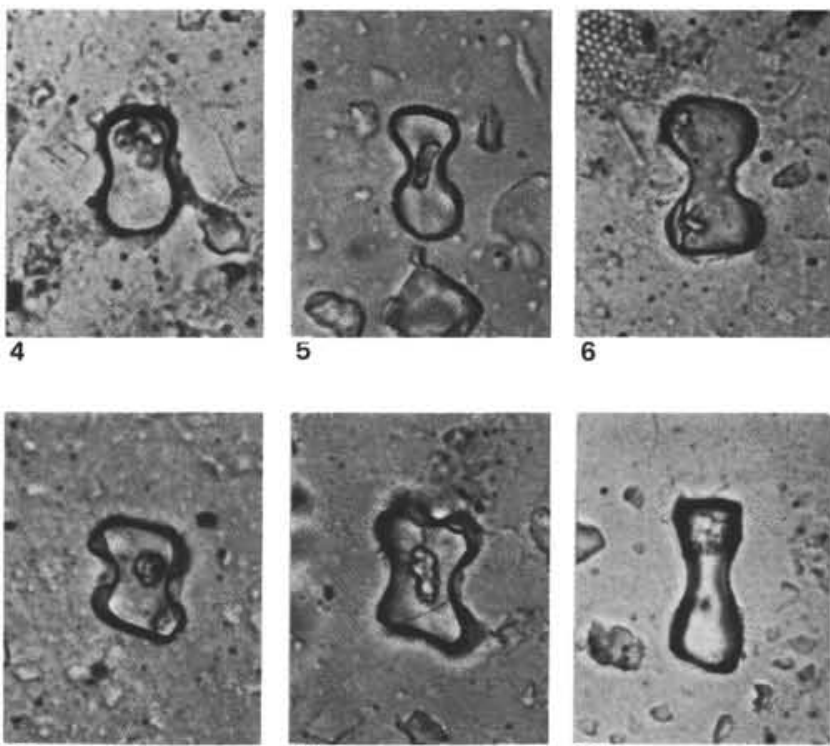

10

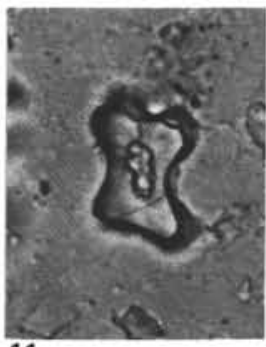

11
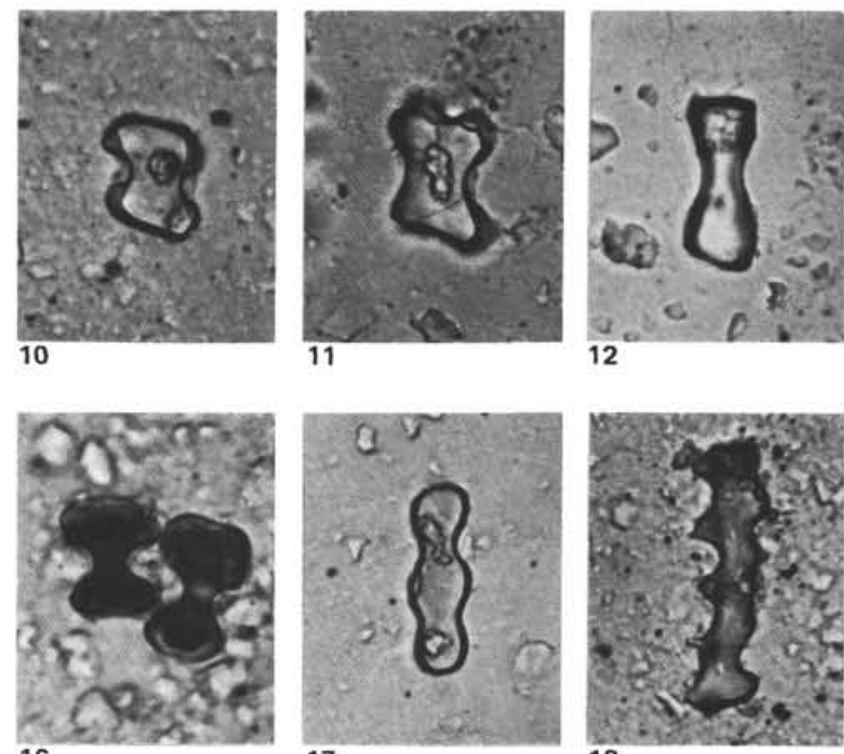

16

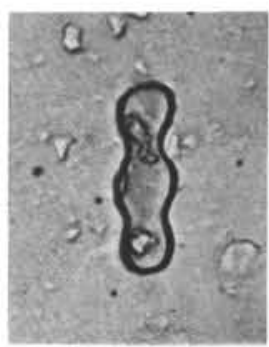

17

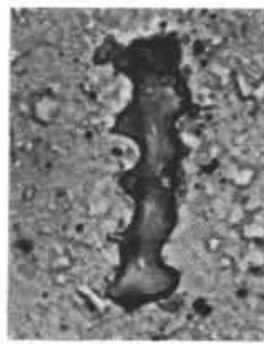

18

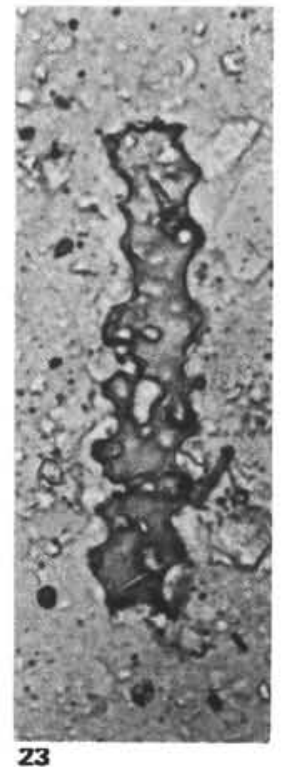

Plate 1. Middle Miocene to Pleistocene phytoliths. (All specimens magnified $\times 800$, bar $=10 \mu \mathrm{m}$ ). 1-3. Lithodontioid phytoliths, (1) Sample

591A-4,CC, Quaternary; (2) Sample 591A-7,CC, upper Pliocene; (3) Sample 591-11,CC, upper Pliocene. 4-17. Lithomesitoid phytoliths, (4) Sample 591-14,CC, lower Pliocene; (5) Sample 591A-4,CC, Quaternary; (6) Sample 591-31,CC, upper Miocene; (7) Sample 591-17,CC, lower Pliocene; (8) Sample 591B-16,CC, middle Miocene; (9) Sample 591A-4,CC, Quaternary; (10) Sample 591-21,CC, lower Pliocene; (11) Sample 591-17,CC, lower Pliocene; (12) Sample 591A-4,CC, Quaternary; (13) Sample 591-11,CC, upper Pliocene; (14) Sample 591-20,CC, lower Pliocene; (15) Sample 591-22,CC, lower Pliocene; (16) Sample 591-13,CC, lower Pliocene; (17) Sample 591A-7,CC, upper Pliocene. 18-23. Lithostyloid phytoliths, (18) Sample 591A-8,CC, upper Pliocene; (19) Sample 591A-4,CC, Quaternary; (20) Sample 591-13,CC, lower Pliocene; (21) Sample 591A-9,CC, upper Pliocene; (22) Sample 591A-4,CC, Quaternary; (23) Sample 591A-3,CC, Quaternary. 24. Silicified epidermis, Sample 591-28,CC, upper Miocene. 